\title{
Sir John Lavery's The Dentist (Conrad Ackner and his Patient)
}

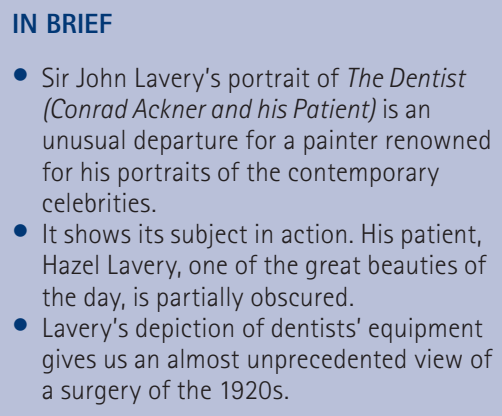

- It shows its subject in action. His patient, Hazel Lavery, one of the great beauties of the day, is partially obscured.

- Lavery's depiction of dentists' equipment gives us an almost unprecedented view of a surgery of the 1920 s.

The rise of the dental profession coinciding with the invention and rapid spread of photography means that there are very few paintings of dentists in action. The present article describes Sir John Lavery's unusual depiction of The Dentist (Conrad Ackner and his Patient) in which the conventions of contemporary society portraiture are set aside. The resulting canvas has much to tell us about the up-to-date equipment used in a surgery of the late twenties by a successful practitioner who pioneered the use of X-rays.

In 1929, Sir John Lavery exhibited one of his most striking portraits - The Dentist (Conrad Ackner and his Patient) (Fig. 1).

Famed for his pictures of society hostesses, political leaders and members of the Royal Family, Lavery had recently developed a new strand within his work that he referred to as 'portrait interiors.' ${ }^{1}$ Forty years earlier, as a young painter in a world dominated by weeklies such as The Graphic and The Illustrated London News, he had witnessed the decline of the romantic and mythological subject matter associated with the Pre-Raphaelites and Neo-Classicists. The artist-reporter on contemporary events was in demand, as were the first stirrings of what we now refer to as 'celebrity culture'. Subsequent Edwardian 'swagger' portraiture did much to inflate the personality cults of the day, and by the twenties, a subtler approach was required. Lady Cunard, Lady Diana Cooper, Count John McCormack, H. H. Asquith, J. M. Barrie and George Bernard Shaw were to be depicted in the disarray of their studies and salons. Furniture, bric-abrac and pictures on walls portrayed very individual spaces which reinforced the characters of their inhabitants. When these paintings were shown in the United States

Emeritus Professor of Art History, Northumbria University, Lipman Building, Sandyford Road, Newcastle upon Tyne, NE1 8ST

Correspondence to: Professor Kenneth McConkey Email: kenneth_mcconkey@btopenworld.com

Accepted 17 November 2010

DOI: 10.1038/sj.bdj.2011.4

${ }^{\circledR}$ British Dental Journal 2011; 210: 81-85 in 1926, one commentator dubbed the commissions Lavery received in New York, Long Island and Boston as portraits of "millionaires surrounded by their millions.'

The artist was 70 when this new genre emerged. His origins were of the humblest. Orphaned at the age of three in 1859, his childhood was spent in rural Ulster and with a relative in Ayrshire. With little money he managed to take evening classes in Glasgow School of Art and struggled to set himself up as a painter. Legend has it that a fire in his studio resulted in an insurance payout which funded his student years in Paris and a year at the artists' colony in Grezsur-Loing. Returning to Glasgow, it was with works such as The Tennis Party, 1885 (Fig. 2) that he achieved critical acclaim. He then had the astonishing good fortune to be commissioned to paint the State Visit of Queen Victoria to the Glasgow International Exhibition in 1888, and with this came introductions to members of the Court and the Scots aristocracy.
His career blossomed after he moved to London and purchased 5 Cromwell

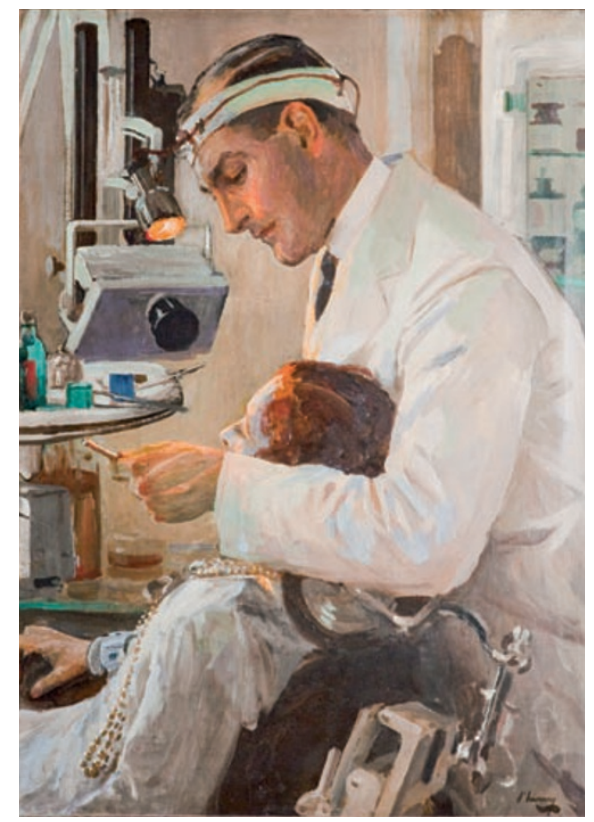

Fig. 1 Sir John Lavery, The Dentist (Conrad Ackner and his Patient), 1929, Private Collection

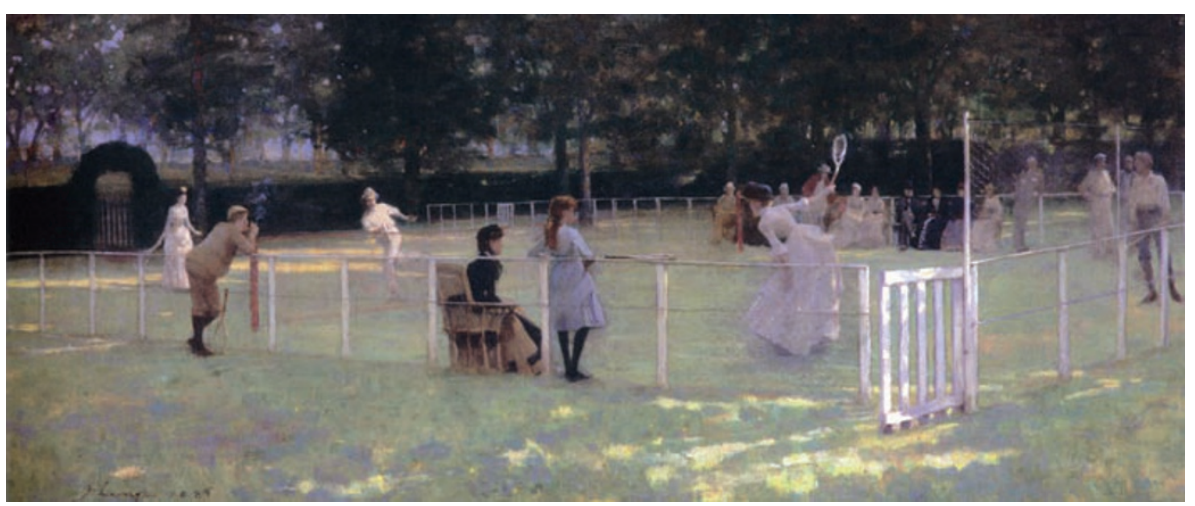

Fig. 2 Sir John Lavery, The Tennis Party, 1885, Aberdeen Art Gallery 


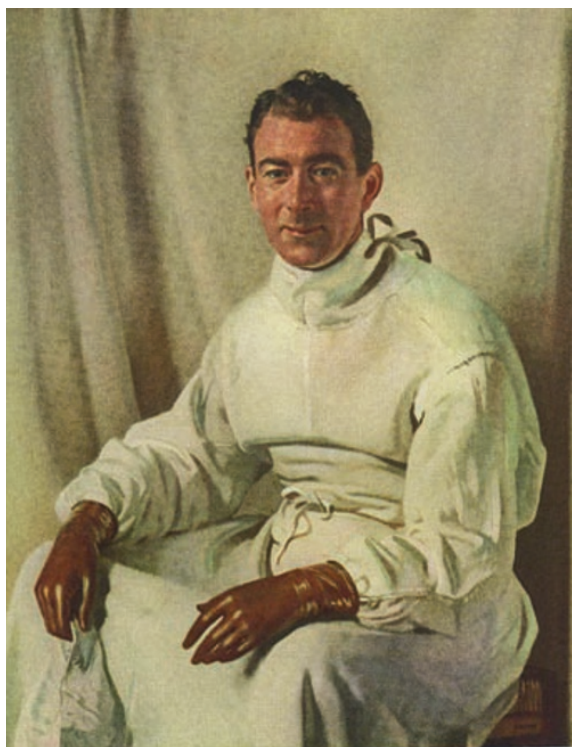

Fig. 3 Sir William Orpen, The Surgeon, Mr Ivor Back, 1926, unlocated

Place, South Kensington in 1898, assisting Whistler and Rodin in the management of the International Society of Sculptors, Painters and Gravers. Marriage in 1909 to an Irish-American beauty, Hazel Trudeau, sealed his good fortune and as London society figures, the Laverys regularly hosted studio lunches, in between attending weekend parties at country houses, race meetings, regattas and other events of the season. Holidaying on the Riviera, flitting regularly to Ireland for the Dublin Horse Show and motoring north to stay with the Londonderrys at Mount Stewart, it would be easy to equate their twenties lifestyle with that of characters from Scott Fitzgerald.

Such a socially ambitious painter may be expected to shun 'difficult' subject matter, but Lavery was never of that disposition. He believed that a painter should be able to paint anything, in any conditions, and this accounts for the enormous range of his work. He was as at home in public baths, in jockeys' weighing rooms and blacksmiths' shops as he was in palaces and grand hotels. As an Official War Artist in his sixties, he had flown in kite balloons over the North Sea convoys and propped his easel on the ice at Scapa Flow to paint the Fleet in the middle of winter. Yet he remained renowned for portraits of such prominent personalities as Winston Churchill, Michael Collins, and Ramsay MacDonald.

It would have been easy when faced with the task of painting a medical man

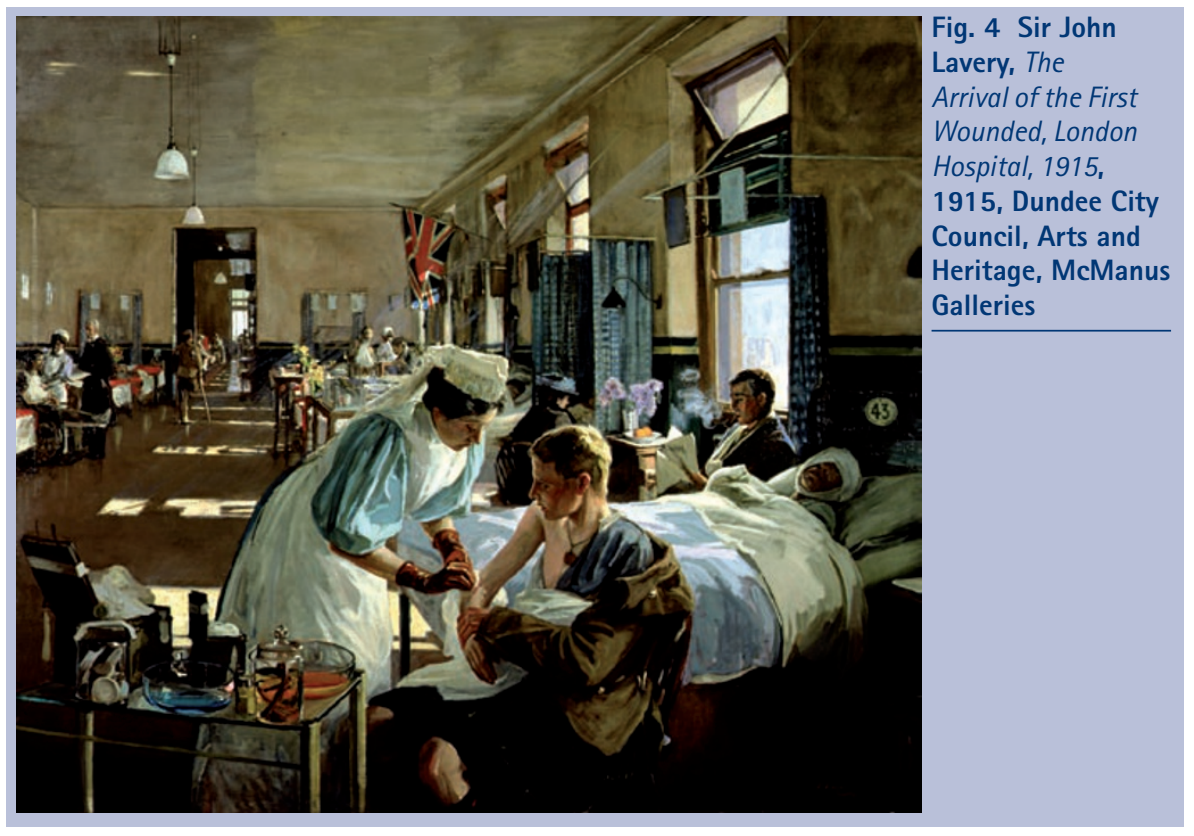

to conform to the standard practice of numerous Victorian face painters and eschew the tools of the trade. Alternatively he might follow William Orpen and show the subject dressed in scrubs wearing sinister rubber gloves as in The Surgeon, $\mathrm{Mr}$ Ivor Back (Fig. 3). But Back was posed in front of a studio drape, rather than in his natural habitat.

Lavery, by contrast, had no fear of the clinical environment. His studio could easily be packed into a portable paint box and he habitually carried $25 \times 30$ inch canvases in a stout wooden box that he had made for the purpose. It was such a field kit that he took to the London Hospital in the opening months of the Great War to paint The Arrival of the First Wounded (Fig. 4), a picture that became his principal Royal Academy exhibit of 1915. ${ }^{3}$ So powerful was the reporter's instinct and so captivating the visual experience that distractions, onlookers and noises off were ignored. In a moment of reflection he once remarked that he was so fond of horses that he could never 'watch' a bullfight, even though passing through Seville and Madrid back in 1892, he had painted five. ${ }^{4}$ Eye and brain turned purely on the visual impact of the scene.

By the end of the 1920s when Lavery was in his early 70s, his powers of concentration remained formidable, and although surrounded by ungainly contraptions, in cramped surgery conditions, the dentist, Conrad Ackner, would

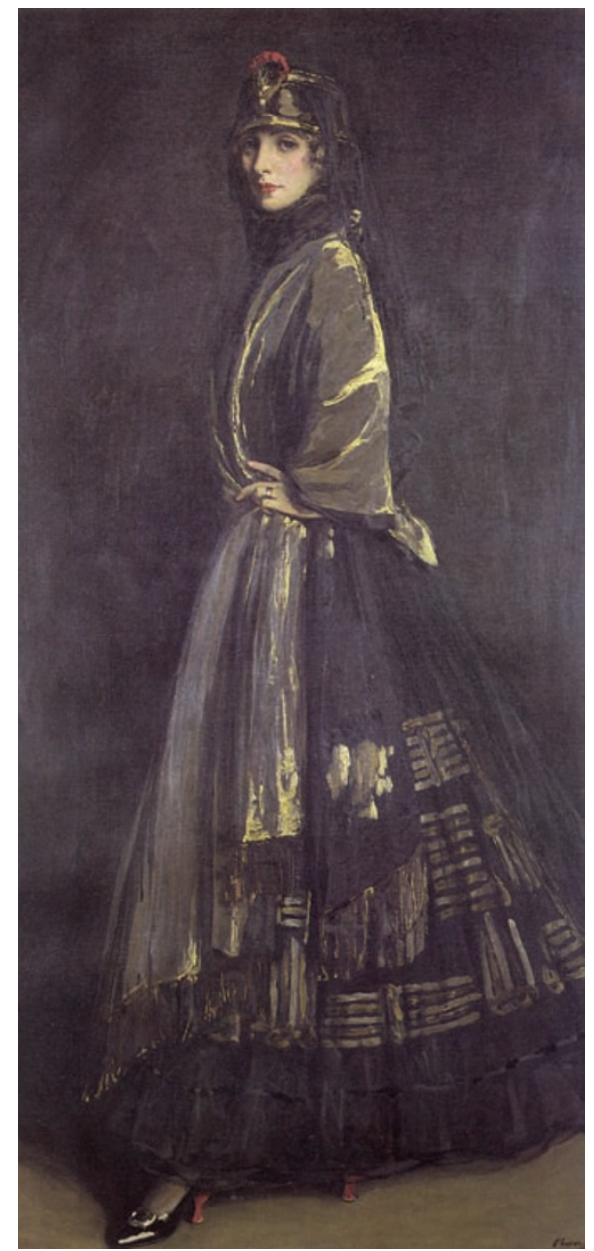

Fig. 5 Sir John Lavery, Hazel in Black and Gold, 1916, Tyne and Wear Museums, Laing Art Gallery, Newcastle upon Tyne

be portrayed with his patient in the chair before him. It remains the case that portraits of dentists in action are extremely rare in the early twentieth century and Lavery's Conrad Ackner and his Patient 
must surely be the most fascinating. Shown at the Royal Society of Portrait Painters' exhibition held in the Grafton Galleries in 1929, it was simply entitled The Dentist. ${ }^{5}$ It shows the artist's wife, Hazel Lavery, undergoing treatment at Ackner's surgery. Contemporary newspaper reports indicate that she was merely a model standing in for one of the dentist's assistants who had agreed to pose. In a press cutting, Lady Lavery is quoted: 'My husband wanted to paint a portrait of Dr Conrad Ackner, an old friend of ours, at work in his beautiful room, surrounded by dental apparatus. At first one of $\mathrm{Dr}$ Ackner's assistants was going to pose in the chair; but I happened to go there one Sunday with my husband, and I sat down in the chair, just for fun. Then Dr Ackner asked me if I would 'oblige' as a model, and I did. The picture is a portrait of $\mathrm{Dr}$ Ackner, of course, and in no sense a portrait of me'.6 Lavery's portraits, such as Hazel in Black and Gold, 1916 (Fig. 5), had conferred celebrity status upon his wife - not least for the fact that she was the face of the Pond's Cream advertising campaign, and featured, in the garb of Kathleen Ni Houlihan, on the Irish Free State currency.

Although it is true that this is Ackner's portrait and not hers, Hazel clearly acted the part - as we can see from the way in which her right hand grips the armrest of the dentist's chair. Ironically it was myocarditis, exacerbated, we are told, by gas and local anaesthetic administered for the removal of a wisdom tooth in November 1933, that led to Hazel's premature death just over a year later. ${ }^{7}$ This may be apocryphal.

\section{CONRAD ACKNER}

Conrad Adolph Achner [sic] was born in 1880 in Ropcha (Ropcze) near Czernowitz, the son of a farmer/landowner (Fig. 6). ${ }^{*} \mathrm{He}$ studied pharmacology at Bern and Vienna Universities, writing a dissertation on the medicinal properties of Chinarinden or Cinchona. He moved to London around

\footnotetext{
*Conrad Adolph Achner (later re-styled as 'Ackner,' 1880-1975) was the son of Heinz Achner. He may have changed the spelling of his surname during the Great War. Ropcha, his place of birth, was then part of the Austro-Hungarian Empire. It later became part of Rumania and is now part of the Ukraine. The author is grateful to Anthony Ackner for notes on his grandfather's early career.
}

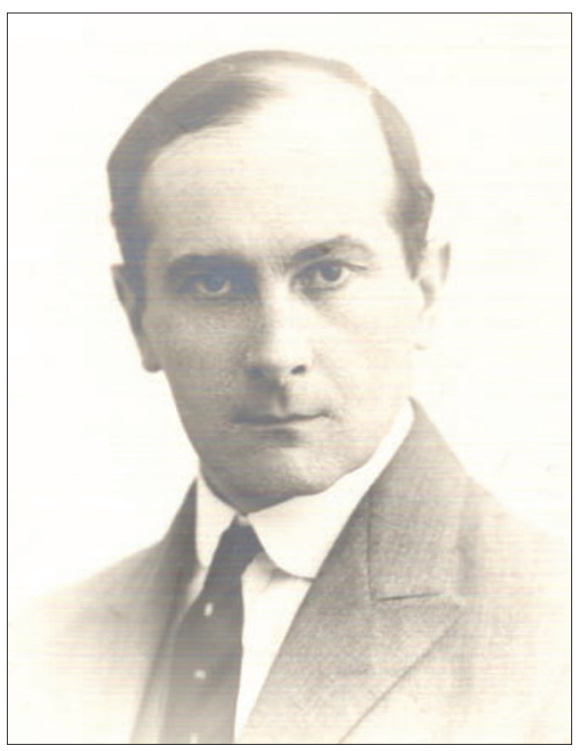

Fig. 6 Conrad Adolph Achner (Ackner, 1880-1975), c. 1930

1910 and may have worked in a pharmacy in Gracechurch Street, before becoming a dental radiographer in Guy's Hospital in London in 1912."

Around this time he married Rhoda Tuck, a member of the Raphael Tuck Greeting Card dynasty. ${ }^{\S}$ The following year he rented one room, which became known as 'the white surgery', in 47B Welbeck Street. The owner, Miss Fanner, lived on the premises and let other rooms to a dentist named Moseley and Dr Weir, later Sir John Weir KCVO, surgeon to the Royal Household." Deploying the new X-ray methods for determining treatment coincided with the rapid growth of Ackner's practice, although

${ }^{\ddagger}$ Ackner's experience of examining over 300 cases at Guy's was reported in a paper entitled 'X-ray observations on abscesses, cysts and root resections', Transactions of the XIth International Dental Congress, 1914, pp 299-305. In these cases Ackner argued for 'the great importance of removing the entire root in extraction, and of also scraping out the granuloma or abscess cavity, and thus preventing further complications...' (p. 305). A year later, Ackner reported on his design of a 'Maxillary Splint' for use in cases of jaw fracture (extract from The Lancet, reported in British Dental Journal 1915; 36: 205-206). This improved on earlie designs, maintaining immobility in the broken bone while permitting normal movement.

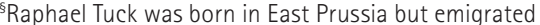
to London in 1865 with his wife and seven children. He opened a framing business and within five years had expanded into publishing Christmas cards. The business prospered and received the Royal Warrant in 1893. Rhoda Tuck, one of Raphael's grandchildren, married Ackner and had four sons, Derek, Brian, Desmond (later Lord Ackner) and John.

Sir John Weir KCVO, (1879-1971) was appointed physician to King George V in 1918 and remained in the Royal Household through the reigns of Edward VIII, George VI and Elizabeth II. He retired in 1968. He and Ackner were close friends, going on motor tours together in Ackner's Bentley. his progress was halted when, during the last year of the Great War, he was interned at Alexandra Palace as a suspected enemy alien and Moseley temporarily took over his patients. After his release, Miss Fanner was initially apprehensive about re-letting to him but she overcame her fears and rented him a large former bedroom, from which the practice rapidly grew.

His move from pharmacology to dentistry runs parallel with the increasing regulation of the profession. Since the Dentists Act of 1878, the establishment of a Dentists Register and the founding of the British Dental Association two years later, growth in the population was mirrored by the proliferation of unqualified practitioners - to such an extent that when Ackner opened his office in 1913, the register included 'the insurance agent, the sewing machine canvasser, the butcher and the blacksmith.8 This situation was remedied by a second Act in 1921 that restricted admission to the profession and set up a Dental Board under the General Medical Council to investigate cases of misconduct. ${ }^{9}$ Canvassing and touting for business was forbidden, and Ackner's use of reproductions of the Lavery paintings in his possession as a subtle form of advertising was also frowned upon.

His choice of premises in Welbeck Street is nevertheless noteworthy. After 1860 the Portland Estate, north of Wimpole Street, with its elegant Georgian houses and proximity to the major railway stations, had become the centre of the medical profession. Within 15 years Ackner's practice occupied 12 rooms in 47B and his patients included members of the Royal Family, the Queen of Norway, and such notables as Marlene Dietrich, Kenneth Clark and John Galsworthy. He also treated Lavery's patron, Sir Patrick Ford ${ }^{10}$ Visits by the Laverys are recorded on consecutive days in July 1926. It may well be the case that the possibility of painting Ackner's portrait was discussed at this time - although falling between trips to the United States it would have been difficult to arrange.

\footnotetext{
Sir Patrick Ford MP (1880-1945) represented Edinburgh North until 1935 and held the post of Solicitor General for Scotland. He organised a Lavery retrospective in Dundee in 1936. Lavery painted his and his mother's portraits in the early years of the century and the two became friends, especially when after the Great War, Ford would stage weekend parties at his villa at Westerdunes, on the outskirts of North Berwick.
} 


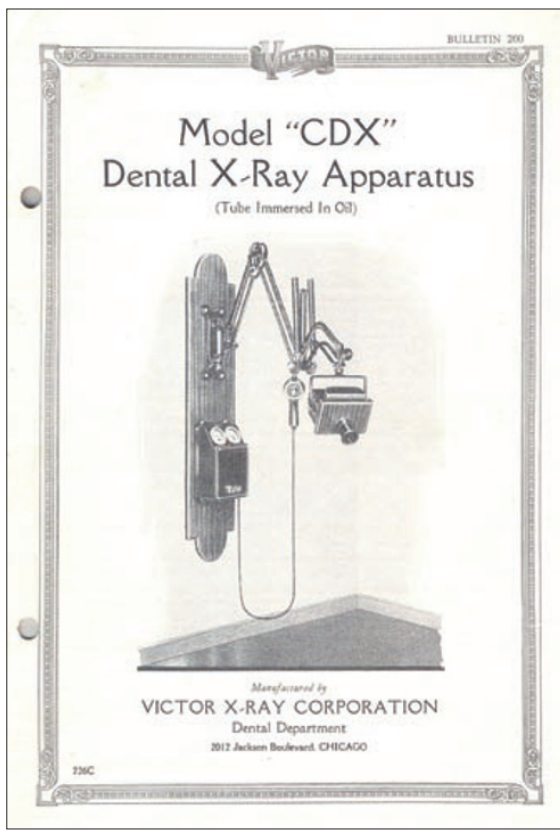

Fig. 7 Victor X-Ray Corporation, Model 'CDX' Dental X-Ray Apparatus, 1921

Lavery's dentist displays calm concentration - his headlamp aimed at the patient's mouth. While not exceptional, battery-operated headlamps were less common than mouth lamps at this time. Claudius Ash and other suppliers included them in their catalogues. ${ }^{11,12}$ The dentist also appears to have used a chair similar to Ash's 'Empire' single cylinder chair, its height adjustable by means of a footpump, ensuring that elevation and lowering were 'accomplished with an entire absence of jar or vibration. ${ }^{13}$ However, the most important piece of equipment, that for which Ackner was regarded as a pioneer, was the dental X-ray apparatus, bearing down on the patient. This is likely to be of American manufacture - specifically the Victor X-Ray Corporation's model 'CDX' which was developed in 1921 by Dr Coolidge (Fig. 7). ${ }^{14}$

Lavery delighted in these tools of Ackner's trade. Others might regard them as ugly and unpaintable, but for him they signified the modernity to which he was committed.

In purely formal terms the subject delivers one of Lavery's most unusual arrangements. Where we might expect the painter to pull back, take in the room, describe the specialist equipment and full positions of the figures, Lavery closes in on the dentist in what are oddly intimate circumstances - circumstances indeed that mimic the treatment process, in which the patient is for the most
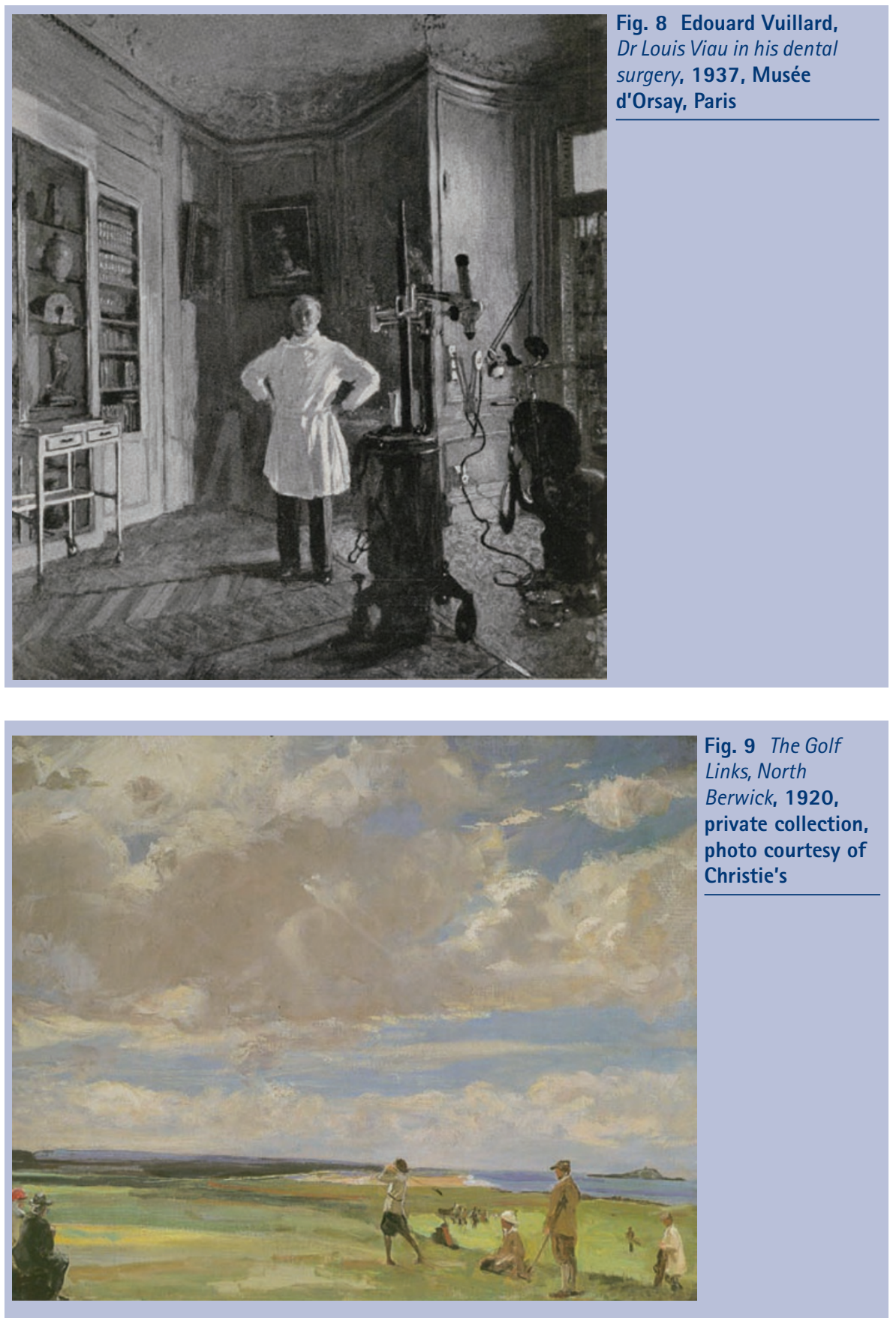

part obscured. Where Edouard Vuillard, in his portraits of Dr Georges Viau in his dental office, 1914 and that of his nephew, $D r$ Louis Viau, 1937 (Fig. 8, both Musée d'Orsay, Paris), delights in the accoutrements and digresses to the fine collections amassed by both practitioners, Lavery excludes all reference to his subject's lifestyle. ${ }^{15-17}$

In fact, like many in the medical profession, Ackner was a collector. He specialised in ivories and among his pictures, visitors to $47 \mathrm{~B}$ Welbeck Street were treated to five works by Lavery. In addition to The Dentist - hanging above the fireplace in Ackner's surgery, there were The Blacksmiths of Tramore, drawn from
Lavery's Irish tour of 1924, and an interior, The Games Room, Lennoxlove House, in East Lothian, while a picture of The Golf Links, North Berwick (Fig. 9), painted close to the entrance of Sir Patrick Ford's country retreat of Westerdunes, may well have been a reminder of one of Ackner's visits north of the border." The final picture, the charming Gardener's Daughter (Fig. 10),

"For The Blacksmiths of Tramore, The Fine Art Society, London, see McConkey 2010, p.165, (Figure 196); the Interior at Lennoxlove, 1921 is in a Private Collection; while The Golf Links, North Berwick, 1921 (sold Christie's Scotland, 31 October 2002) relates to a large work, Playing Golf at North Berwick, which was shown at the Glasgow Institute of the Fine Arts in 1922. This shows the artist's step-daughter, Alice, teeing-off in the presence of the Fords, Asquith and Hazel Lavery. 


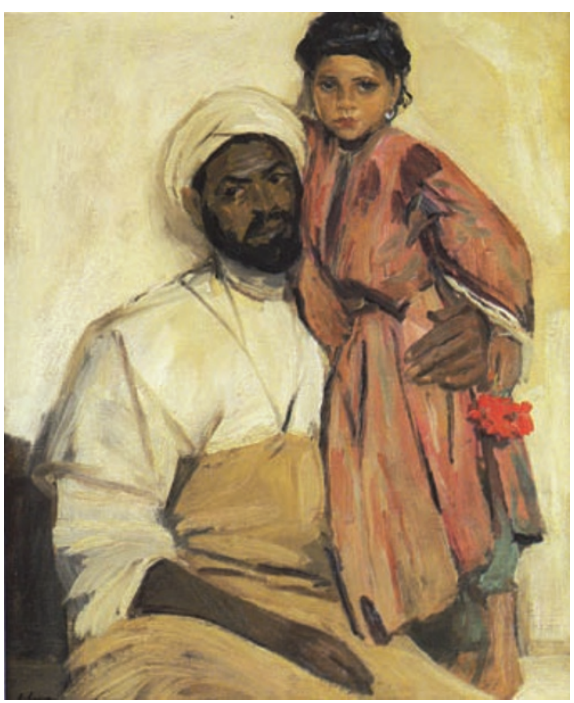

Fig. 10 The Gardener's Daughter, c. 1920, private collection, photo courtesy of Christie's

was painted at Lavery's second home in Tangier.** It was a group of pictures that illustrated the diversity of Lavery's work in the 1920s - studies painted ad vivum were preferred to set-piece portraits, and two favourites, The Golf Links and The Blacksmiths of Tramore were illustrated on Ackner's Christmas cards.

\footnotetext{
**Lavery first visited Tangier in 1891. He purchased a house in the hills to the south of the Medina, overlooking the Straits of Gibraltar in 1903. Known as Dar-el-Midfah, the 'House of the Cannon', it had a rusty cannon in the garden which remains to this day. The house functioned as a winter studio, a base for desert forays and a trip to Fez in 1907. Its extensive garden, with tumbling bougainvilleas, was painted on many occasions. The Gardener's Daughter was sold Christie's, 12 June 1986.
}

However, in form and content none of these canvases is completely unique: at least one other Lennoxlove interior is known; seven Irish pictures are documented from 1924; there are at least fourteen golfing canvases; and Lavery had been painting studies of Moroccan servants since 1892. There are, however, no other portraits of dentists. No revelations about the current state of the practice. No other glimpses into an important new profession which a century earlier had been merely a trade. In this sense, The Dentist (Conrad Ackner and his Patient) surpasses much of Lavery's other commissions of the inter-war period and reminds us once again of a collusion between artist and sitter to paint what aesthetic convention might have regarded as unpaintable.

I am most grateful to Anthony Ackner and Rachel Bairsto for their assistance in the preparation of this article.

1. McConkey K. John Lavery, a painter and his world. pp 166-174. Edinburgh: Atelier Books, 2010.

2. Robins Pennell E. The life and letters of Joseph Pennell. Volume 2. p 340. London: Little, Brown and Co, 1930.

3. McConkey K. John Lavery, a painter and his world. pp 125-127. Edinburgh: Atelier Books, 2010.

4. McConkey K. John Lavery, a painter and his world. p 62. Edinburgh : Atelier Books, 2010.

5. Royal Society of Portrait Painters. Thirty-Eighth Annual Exhibition, November 1929, no. 138, as The Dentist.

6. Unidentified press cutting in The 'Bluebook', a scrapbook presented to Dr Ackner by his staff, 1938, Private Collection.

7. McConkey K. John Lavery, a painter and his world. pp 192-194. Edinburgh: Atelier Books, 2010. 8. Carr-Saunders A M, Wilson P A. The professions. p 112. Oxford: Oxford University Press, 1933.

9. Carr-Saunders A M, Wilson P A. The professions. pp 113-115. Oxford: Oxford University Press, 1933.

10. McConkey K. John Lavery, a painter and his world. pp 147-149. Edinburgh: Atelier Books, 2010.

11. Claudius Ash, Sons and Co Ltd. Dental supplies catalogue, 1928. p F48

12. Dental Manufacturing Co. Catalogue, 1928. p 42

13. Claudius Ash, Sons and Co Ltd. Dental supplies catalogue, 1928. pp C4-C7.

14. Victor X-Ray Corporation. Model "CDX" Dental X-Ray Apparatus, Bulletin 260, n. d., 212 Jackson Boulevard, Chicago.

15. Cogeval $\mathrm{G}$ et al. Edouard Vuillard, 2003. Exhibition catalogue, National Museum of Art, Washington and Montreal Museum of Fine Arts. pp 348-349.

16. Thomson B. Vuillard. pp 131. Oxford: Phaidon, 1988

17. Roger-Marx C. Vuillard, his life and work. pp 117-118. London: Paul Elek, 1946.

Please help the BDA Museum acquire this important painting of a fashionable London dental practice. 'The Dentist' by Sir John Lavery depicts Conrad Ackner in his surgery at 47B Welbeck Street in 1929. The Museum needs to raise $€ 60,000$ and is hoping to raise the majority of funds from the VCtA/MLA Purchase Grant Fund and The Art Fund. If successful with these grants we would need to contribute approximately $€ 12,000$.

We gratefully acknowledge the donation of $£ 1,000$ from the Lindsay Society for the History of Dentistry to kickstart our campaign.

To make a donation or for further details, please contact Rachel Bairsto at the museum on $02075635832 / 4549$ or r.bairsto@bda.org. Further information about the painting can be found at www.bda.org/lavery.

The BDA Museum is part of the BDA Trust Fund and a registered charity No 313407 . If you are a UK tax payer we are able to maximise your donation through gift aid.

For an opportunity to view the painting 'The Dentist' by Sir John Lavery please visit the BDA library where it is on display. 